\title{
Download
}

UDC 72.04:75.036+338.48

https://doi.org/10.17721/2308-135X.2019.5

4

$41-49$

Romaniv Oksana Yakivna, Candidate of Geography, Associate Professor, State University "Zhytomyr Polytechnic", Zhytomyr

, Ukraine,

e-mail:

okromaniv

@

gmail

com

Rybachok Oleksii Mykolayovych, State University "Zhytomyr Polytechnic", Zhytomyr, Ukraine, e-mail:

$\underline{\text { les }}$

ha.r.2018@gmail.com

Savelyeva Daria Vitaliivna, State University "Zhytomyr Polytechnic", Zhytomyr, Ukraine, 
e-mail: tanechka_saveleva_71@mail.ru

\section{STREET ART IN THE SPACE OF THE TOURIST ENVIRONMENT OF ZHYTOMYR}

The aim - to study the main characteristics of the tour "Street art Zhitomir" and its strategy to promote on the urban tourism market.

Research methodology includes a system of methods and techniques: monographic, methods of market research (applied in the study of the existing demand for the proposed type of travel products and attitudes of local people to the street art), interviews with experts (used in collecting information about sightseeing objects), the method of field research (used in the study of the actual state of excursions subjects in real-world conditions of the area).

Research results. Reviewed the role of street art in urban space rethinking the example of prominent projects in the world. Established terminological meaning of "street art", "mural", "graffiti" and so on. The benefits of increasing the popularity of street art are noted.

Wall painting or mural (in Spanish muro - "wall", "masonry") - a kind of monumental and decorative painting, performed directly on the wall or plaster, in which the images and decorative ornaments are subordinated to architectural forms.

It allows to improve urban landscapes in combination with post-Soviet architecture. Other positives of street art are: creating landmarks, designing space, marking space, and more. A separate positive of the Murals: they help attract more tourists to the cities. The text of the publication gives examples of murals in famous tourist centers, which have helped to transform the urban space.

The article discusses the importance of street art as one of the most popular and fastest growing types of contemporary art in shaping the space of the urban tourism environment of Zhytomyr. It defines the role of murals as the most common direction of Zhytomyr street art. The results of the study of the most famous and significant murals of the city of Zhytomyr by 
available sources of information are presented, the possibility of their involvement in the excursion program is analyzed. The main components of the excursion product "Street Art Zhytomyr" in the publication are developed. The tools for promoting the proposed excursion product to the urban tourism market are identified.

The scientific novelty of the work: an innovative city excursion product was developed. The excursion program includes fifteen locations. The content of the tour is designed for both professional artists and those who are not experts in the field of art.

The practical significance of the work: this excursion product can be introduced into the tourism market and it will contribute to the formation of a positive tourist image of the city of Zhytomyr.

Keywords: street art; mural; urban tourism; excursion product.

References

1.10 incredible mural of Ukraine: rating from CityOboz. [Electronic resource]. - URL: https://ww w.obozrevatel.com/ukr/city/journal/10-nejmovirnih-muraliv-ukraini-rejting-vid-cityoboz.htm

2. Vorotnev V. Incontinence: Why Kiev murals are not moralism, street art or graffiti. [Electronic resource

URL:

https://hmarochos.kiev.ua/2016/10/11/netrimannya-mezhi-chomu-kiyivski-stinopisi-ne-ye-mural ami-strit-artom-chi-grafiti/ 
3. Golynko-Wolfson D. Street art: theory and practice habitation street environment // Art magazine. $\underline{\text { ne.com/issue/16/article/225 }}$

[Electronic resource]. - URL: http://moscowartmagazi

4. Hrytsiuk K. Mural: a new approach to the old art. [Electronic resource]. - URL: http://uk.theo utlook.com.ua/article/5056/murali-novij-p\%D1\%96dx\%D1\%96d-do-starogo-mistetstva.html

5. Demus Y. Zhytomyr may become the graffiti capital of Ukraine. [Electronic resource]. - URL: https://www.1.zt.ua/news/misto/zhitomir-mozhe-stati-grafiti-stolitseyu-ukrayini-foto.html

6. Demus Y. Steve Jobs's mural has appeared in Zhytomyr. [Electronic resource]. - URL: https ://www.1.zt.ua/news/misto/u-zhitomiri-zyavivsya-mural-stiva-dzhobsa-foto.html

7. The residents of Zhytomyr call for a bicycle excursion. [Electronic resource]. - URL: https://z hitomir-online.com/suspilstvo/62373-zhytomyryan-klychut-na-veloekskursiyu-muraly-zhytomyra $\underline{\mathrm{html}}$

8.Space and bright, new graffiti in Zhytomyr. [Electronic resource]. - URL: https://www.1.zt.ua/ themes/misto/kosmichni-ta-yaskravi-novi-grafiti-u-zhitomiri.html

9.Podnos Varvara, Verbyts $\square$ kyy Ivan, Tyshchenko Ihor, Hryshchenko Mariya. Murals - the embodiment of symbolic power to change the image of the city. [ Electronic resource]. - URL: https://mistosite.org.ua/ru/articles/muraly-vt\%D1\%96lennya-symvol\%D1\%96chnoyi-vlady-dlyazm\%D1\%96ny-obrazu-m\%D1\%96sta

10.Mural: From Philadelphia to Rabat. [Electronic resource]. - URL: https://www.bbc.com/ukrai nian/features 
11.Chernyaeva K. Wall painting: TOP-10 murals of Ukraine according to Dobovo. [Electronic resource

URL:

https://www.dobovo.com/blog/uk

12. Top 10 travel trends. Pinterest is predicting for 2018. [Electronic resource]. - URL: Pinterest.com 